- бути уважним слухачем;

- вербальної та невербальної взаємодії з молодшими школярами;

- усвідомлювати, систематизувати, переносити інформацію, отриману в процесі спілкування;

- усвідомлювати мету спілкування, пошук способів його організації в різних видах діяльності;

- організовувати спонтанне спілкування учнів;

- усвідомлювати мотиви вибору та способу організації спілкування учнів.

Визначення можливості й необхідності організації спілкування молодших школярів потребує спеціальної професійної підготовки майбутніх учителів. Результат такої підготовки студентів визначається рівнем готовності майбутніх учителів початкових класів до організації спілкування учнів. Перспективою спеціального дослідження вважаємо розгляд питання підготовки майбутніх учителів початкових класів до організації спілкування учнів в умовах виховної роботи.

\title{
Література
}

1. Виевская М. Г. Формирование готовности будущего учителя к педагогическому взаимодействию с учащимися: дисс. ... канд. пед. наук: 13.00.01./ Виевская Муза Георгиевна. - Кривой Рог, 1994. - 165 с. 2. Кондрашова Л. В. Методика подготовки будущего учителя к педагогическому взаимодействию с учащимися / Л.В.Кондрашова. Москва : Прометей, 1990. - 160 с. 3. Мороз А. Г. Формирование готовности к педагогической деятельности молодых учителей / А. Г. Мороз // Психолого-педагогические основы совершенствования подготовки специалистов в университете. - Днепропетровск, 1980. - С. 71-75. 4. Савченко О. Я. Дидактика початкової школи: [підручник для студентів педагогічних факультетів] / О. Я. Савченко. - Київ : Абрис, 1997. - 416 с. 5. Сластенин В. А. Профессиональная готовность учителя к воспитательной работе: содержание, структура, функционирование / В. А. Сластенин // Профессиональная підготовка учителя в системе высшего педагогического образования. - Москва : Педагогика, 1982. - 151 с.

Віра Перепьолка

\section{ФОРМУВАННЯ ПРОФЕСІЙНОЇ МОВНОКОМУНІКАТИВНОЇ КОМПЕТЕНТНОСТІ МАЙБУТНІХ УЧИТЕЛІВ ПОЧАТКОВИХ КЛАСІВ}

Перепьолка В. I. Формування професійної мовнокомунікативної компетентності майбутніх учителів початкових класів.

У статті розглядається одна із важливих концепцій державної мови - формування професійної мовнокомунікативної компетентності майбутніх учителів початкової школи, аналізуються технології іï реалізації. Це формування значною мірою залежить не від отриманих знань, а від деяких додаткових якостей, для позначення яких і використовуються поняття «компетенція» i «компетентність», що найповніше відповідають сучасному розумінню мети освіти.

Ключові слова: компетентність, професійна компетенція, мовнокомунікативна компетентність, педагогічні технології, комунікативна ситуація, мовний і мовленнєвий аспекти, культура мовлення.

Перепьолка В. И. Формирование профессиональной речевой компетентности 
будущих учителей начальных классов.

В статье рассматривается одна из важных концепций государственного языка формирование профессиональной речевой компетентности будущих учителей начальных классов, анализируются технологии ее реализации. Это формирование в значительной степени зависит не от полученных знаний, а от некоторых дополнительных качеств, для обозначения которых и используют понятия «компетенция» и «компетентность», которые соответствуют современному понятию цели образования.

Ключевые слова: компетентность, профессиональная компетенция, речевая компетентность, педагогические технологии, коммуникативные ситуации, речевой и языковой аспекты, культура речи.

Perepolka V. I. The formation of professional speech communicative competence of future primary school teachers.

The article examines one of the most important concepts of the official language - the formation of professional speech communicative competence of future primary school teachers, the technologies of its realization are analysed in the article. The formation mostly depends not on the received knowledge, but on some additional skills named «competence» and «competency». They correspond to the modern understanding of the educational purposes.

Key words: competence, professional competence, speech communicative competence, pedagogical technologies, communicative situation, speech and language aspects, speech culture.

Актуальною проблемою сучасної лінгводидактики та психолого-педагогічної науки і практики $\epsilon$ формування професійної мовнокомунікативної компетентності майбутніх учителів початкової школи, оскільки від іiї розв'язання залежить якість професійної підготовки i майбутньої педагогічної діяльності студентів. Саме ця компетентність концентрує у собі спрямованість особистості, їі здатність долати стереотипи, передбачати проблеми, гнучкість мислення. Тому одним із головних завдань вищих навчальних закладів $\epsilon$ пошук найбільш ефективних форм роботи щодо формування професійної мовнокомунікативної компетентності учителів початкових класів.

До проблеми визначення професійної компетентності педагога зверталися такі провідні науковці, як Н. Кузьміна, В. Лозова, В. Хуторський та ін. Різні аспекти професійної компетенції досліджують С. Вітвицька, О. Вознюк, М. Левківський та ін.

Суттєве значення для теоретичного і практичного розвитку цієї проблеми мають науково-практичні дослідження М. Алексєєвої-Вовк, Д. Бараник, О. Біляєва, Л. Виготського, Т. Гриценко, І. Зимньої, О. Кислої та ін.

Mema cmammi- виявити особливості і шляхи формування професійної мовнокомунікативної компетентності майбутніх учителів початкових класів.

«Особистість виховує особистість»- це азбука виховного процесу. Тому виняткову роль відіграє перший учитель у навчанні й вихованні дитини-молодшого школяра. Особистість педагога надає процесу навчання ціннісно-значущу спрямованість і своєрідність впливу через індивідуальну культуру спілкування, поведінку, почуття тощо. Тому основою професійної підготовки педагога XXI ст. стає розвивальна складова виховання особистості, яка здатна до самоосвіти і саморозвитку, вміє критично мислити, опрацьовувати інформацію, використовувати набуті знання і вміння для творчого розв'язання проблем, усвідомлює свою відповідальність, постійно працює над особистісним і професійним зростанням, уміє досягати поставлених цілей. 
Звернення до поняття «професійна педагогічна компетентність» у теорії та практиці професійної освіти викликано рядом об'єктивних і суб'єктивних чинників. У цьому випадку актуалізується проблема професійно-педагогічної підготовки вчителя, від рівня якої фактично залежить успішний розвиток вітчизняної системи освіти [5, с. 25].

Професійну компетентність ми розглядаємо як сукупність знань 3 професійно орієнтованих дисциплін (педагогіка, психологія, методика) та вмінь їх практично використовувати у професійній діяльності. У сучасних умовах відкритого доступу до будьякої інформації професійних знань учителя визначається не тільки змістом цих знань, а й здатністю передавати їх таким способом, який сприяє взаємодії, обговоренню, діалогу, аргументації [6, с. 570].

Підвищення компетентності педагогічних кадрів в умовах змін є одним із основних чинників досягнення успіху у всіх сферах розвитку освітньої системи. Під цим кутом зору роль учителя полягає не лише в тому, щоб забезпечити трансляцію знань, але й бути носієм культури і вселюдських цінностей, провідником ідей державотворення і демократичних змін.

Домінантною стає підготовка педагога, діяльність якого не обмежується викладанням власного предмета, а здатного до здійснення міждисциплінарних зв'язків, який усвідомлює значущість професійних знань у контексті соціокультурного простору. Важливим є його вміння організувати навчальний процес як педагогічну взаємодію, спрямовану на розвиток особистості, її підготовку до розв’язання завдань життєтворчості.

Нові педагогічні технології, упроваджуваня у сучасній загальноосвітній школі, потребують фахової підготовки педагога, посилення дослідницького компонента у професійній діяльності майбутнього вчителя. Згідно з Державним стандартом початкової загальної освіти, затвердженого Кабінетом Міністрів України 20 квітня 2011 р., основним завданням початкового навчання $\epsilon$ «...реалізація особистісно зорієнтованого i компетентнісного підходів та оволодіння учнями ключовими компетентностями: уміння вчитися, соціально-трудова компетентність, загальнокультурна, інформаційнокомунікативна, здоров'язбережувальна, соціальна [4, с. 8]. Це означає, що в майбутнього вчителя ці компетентності теж повинні бути сформовані. Крім того, важливого значення набуває формування соціально активної особистості, здатної об'єктивно оцінювати дійсність, сформувати і відстояти власну думку, бути активним учасником життєвих процесів. Майбутній учитель повинен підвищувати рівень свого професіоналізму та педагогічної майстерності, вести творчий пошук. Функції професійної діяльності вчителя початкових класів навіть ширші, ніж у вчителя-предметника, оскільки він $є$ класним керівником і викладає різні предмети. Ось чому майбутній учитель початкових класів зобов'язаний мати якісну психолого-педагогічну, методичну підготовку 3 аксіологічних (ціннісних) питань навчання і виховання дітей.

Отже, професійно-компетентною є така праця вчителя, в якій на достатньо високому рівні здійснюється педагогічна діяльність, педагогічне спілкування, реалізується особистість майбутнього вчителя і досягаються результати навчання та виховання школярів.

Людина може бути професіоналом у своїй сфері, але не бути компетентною у розв'язанні всіх професійних питань. Тому доцільно вивчати окремі аспекти професійної компетентності фахівця, з-поміж яких етична має вагоміше значення, оскільки передусім моральні цінності й установки визначають мету, стратегію і тактику педагогічної дії.

Домінуючим блоком професійної компетентності майбутнього вчителя є такі системні характеристики:

- мотивація (спрямованість особистості та її види); 
- якості (педагогічні здібності, характер і його риси, психологічні стани та процеси);

- інтегральні характеристики особистості (педагогічна самосвідомість, індивідуальний стиль, креативність).

Компетентність майбутнього вчителя не має бути вузькопрофесійною, оскільки від нього вимагається постійне осмислення різноманітних соціальних, психологічних, педагогічних та інших проблем, пов'язаних з освітою. Щоб підтримувати в учнів стійкий пізнавальний інтерес, вчителю необхідно бути обізнаним в усіх сферах життєдіяльності, володіти інформацією про події у світі, різні винаходи та новинки науки і техніки. Для цього потрібно працювати 3 різноманітними джерелами інформації та спонукати учнів до пошукової діяльності. «Щоб відкрити перед учнями іскорку знань, майбутньому вчителю треба ввібрати в себе море світла, ні на хвилину не відходячи від променів вічно сяючого сонця знань» [7, с. 75].

Формування вчителя нового типу можливе лише за умови наближення навчання у ВНЗ до реальної професійної діяльності, адже становлення вчителя визначається не лише глибокими знаннями, а й удосконаленням його професійних умінь і навичок у практичних діях. Саме тому формування компетентності майбутніх учителів початкових класів повинно здійснюватись за допомогою новітніх технологій навчання. Одним із найперспективніших шляхів удосконалення підготовки майбутніх учителів $є$ впровадження у навчальний процес активних форм та методів навчання.

Особлива роль сьогодні відводиться інтерактивному навчанню, тобто навчанню, зануреному у спілкування. Тому лекція-монолог поступається лекції-діалогу. Це дає можливість студентам набути досвіду демократичної поведінки та комунікативної взаємодії, що стимулює якість мовленнєвого процесу. Крім того, студент набуває досвіду ведення професійної полеміки.

Семінарські заняття $є$ однією $з$ важливих форм організації навчального процесу у ВН3. Створення демократичного настрою під час проведення семінарських занять $\epsilon$ можливим за умови виконання певних правил: чітко формулювати власну точку зору, вести коректний діалог, уникати поспішних висновків, вислухати співбесідника до кінця, зацікавити його власною точкою зору, знайти раціональне зерно в чужій думці, не зловживати часом розмови, досягти спільної думки і захистити її перед групою.

Під час занять викладач має створювати такі комунікативні ситуації, які стимулюватимуть мовленнєву активність студента. Особливу увагу слід приділити спонтанному мовленню, яке часто виникає під час професійного спілкування і потребує готовності до нього. Спонтанне мовлення ускладнює спілкування, а відтак може негативно вплинути i на рівень культури мовлення. Воно виключає можливість попереднього обмірковування, що може призвести до граматичних i стилістичних помилок. Тому позитивний вплив на розвиток мовленнєвої культури має використання діалогічних вправ, рольових ігор та проектної роботи. Ці види навчальної діяльності допомагають виробляти навички побудови логічного висловлювання, уміння й навички аргументування, закріпити стійкі навички функціонально-правильного професійно-орієнтованого усного і писемного мовлення, сприяють практичній реалізації комунікативно-творчого потенціалу студентів. Крім того, розвиваються ініціативність, здатність брати на себе відповідальність, самоконтроль, організаційні уміння (розподіл обов'язків, планування, контроль, прийняття рішень тощо). Отже, студенти набувають досвіду розв'язання фахових проблем завдяки професійному спілкуванню, вчаться більшою мірою спиратися на використання вміння аргументувати свою позицію, переконувати опонента, вибудовувати власну тактику i 
стратегію поведінки залежно від ситуації професійного спілкування, дотримуючись при цьому норм культури мовлення.

Звертаючись головним чином до діалогічного мовлення, не слід недооцінювати роль монологічного мовлення. У цьому випадку студенти навчаються готувати промову, складати iï план і користуватися ним, спиратися на ключові слова і поняття, робити вступ до публічного виступу і мотивувати при цьому слухачів до слухання, говорити короткими $\mathrm{i}$ зрозумілими реченнями, пояснювати терміни, описувати складні явища, наводити приклади для унаочнення викладеного матеріалу.

Студентів потрібно орієнтувати на те, що вибір доказів на користь чи на захист певної ідеї має спрямовуватися на усунення сумнівів, що виникають у співрозмовника (додаткові пояснення, уточнення інформації, звернення до розгляду нових аспектів проблеми, переконливі відповіді на запитання опонента тощо). Аргументація буде вдалою, якщо використовувати зрозумілі для опонента приклади, застосовувати покликання на його власну позицію, порівняння, швидко орієнтуючись при цьому на реакцію партнера.

Надзвичайно важливим є мовний і мовленнєвий аспекти аргументації. Автор навіть найкращої ідеї не зуміє переконати свого опонента, якщо не зможе дібрати зрозумілі для нього слова, якщо тон його звернення не буде доречним у певній ситуації і щодо певного співрозмовника. Нечіткість вимови, плутаність у лексичних засобах, невідповідність стильового забарвлення заважають реалізації професійного завдання.

Мовленнєві засоби, які добираються для аргументації, мають бути зрозумілими i доступними для опонента. При висловленні та аргументації власної точки зору треба бути об'єктивним, коректним, ввічливим, дотримуватися мовленнєвого етикету, в жодному разі не допускати образливих для опонента висловів.

Сучасний компетентний фахівець має вміти логічно, чітко і адекватно висловлювати свою думку; володіти апаратом аргументування; займати активну позицію під час виробничих нарад, обговорень, «круглих столів»; виступати з пропозиціями; знаходити адекватні прийоми професійного спілкування зі співробітниками i колегами різного ієрархічного рівня; здійснювати виступи перед аудиторією, робити презентації; володіти мовленнєвим етикетом. Недостатня комунікативна підготовка, нездатність організувати фахове спілкування, відсутність певних умінь і навичок спілкування, низький рівень культури професійного спілкування різко знижують «вартість» спеціаліста на ринку праці, можливості його працевлаштування, успішність виконання ним професійних обов'язків, особливо у нестандартних ситуаціях.

Формування професійної мовнокомунікативної компетенції передбачає:

- глибокі професійні знання і оволодіння понятійно-категоріальним апаратом певної професійної сфери та відповідною системою термінів;

- досконале володіння сучасною українською літературною мовою;

- уміле професійне використання мовних стилів і жанрів відповідно до місця, часу, обставин, статусно-рольових характеристик партнера (партнерів);

- знання етикетних мовних формул і вміння ними користуватися у професійному спілкуванні;

- уміння працювати з різними типами текстів;

- орієнтування в потоці різнотемної та різнотипної інформації українською мовою на різних каналах її передавання;

- уміння знаходити, вибирати, сприймати, аналізувати та використовувати інформацію профільного спрямування; 
- володіння інтерактивним спілкуванням, характерною ознакою якого є необхідність миттєвої відповідної реакції на повідомлення чи інформацію, що знаходиться в контексті попередніх повідомлень;

- володіння основами риторичних знань і вмінь;

- уміння оцінювати комунікативну ситуацію швидко і на високому професійному рівні приймати рішення та планувати комунікативні дії.

Отже, професійна мовнокомунікативна компетенція особистості $\epsilon$ показником сформованості системи професійних знань, комунікативних умінь і навичок, ціннісних орієнтацій, загальної гуманітарної культури, інтегральних показників культури мовлення, необхідних для якісної професійної діяльності. Сформувати професійну мовнокомунікативну компетенцію покликана сучасна система освіти.

\section{Література}

1. Адамова А. М. Інтерактивні форми роботи на уроках української мови та літератури / А. М. Адамова // Вивчаємо українську мову та літературу. - 2007. - № 33 (145). - С. 8-10. 2. Алексєєва-Вовк М. І. Мовознавча підготовка студента як складник його загальної культури (лексична)/ Наукові записки кафедри педагогіки Харківського національного університету імені В. Н. Каразіна: [зб. наук. праць]. - Харків : Основа, 2004. Вип. 12. 3. Гриценко Т. Б. Українська мова та культура мовлення: [навч. посіб. для студ. вищ. навч. закл.] / Т. Б. Гриценко. - Київ : Центр навчальної літератури, 2005. - 534 с. 4. Державний стандарт початкової загальної освіти, затверджений постановою Кабінету Міністрів України від 20 квітня 2011 року № 462. [Електронний ресурс]. - Режим доступу : http: //osvita.ua/legisiation/Ser_osv/ 17911/ 5. Дубасенюк О. А. Креативний підхід до професійно-педагогічної підготовки майбутніх учителів / О.А.Дубасенюк // Креативна педагогіка. - 2011. - № 4. - С. 23-28. 6. Пуховська Л. П. Сучасні дослідження в галузі педагогічної освіти у країнах Західної Європи / Неперервна професійна освіта: проблеми, пошуки, перспективи: [монографія] / за ред. І. А. Зязюна. - Київ : Віпол, 2000. - С. 565-589. 7. Сухомлинський В. О. Вибрані твори в п’яти томах. - Київ : Рад. шк., 1976. - С. 419-656.

УДК 378.147.091.33

Діна Тюріна

\section{ПЕДАГОГІЧНІ УМОВИ ФОРМУВАННЯ ВМІНЬ МОДЕЛЮВАННЯ У СТУДЕНТІВ ВИЩИХ ЕКОНОМІЧНИХ НАВЧАЛЬНИХ ЗАКЛАДІВ У ПРОЩЕСІ САМОСТІЙНОЇ НАВЧАЛЬНОЇ ДІЯЛЬНОСТІ}

Тюріна Д. М. Педагогічні умови формування вмінь моделювання у студентів вищих економічних навчальних закладів у процесі самостійної навчальної діяльності.

У статті здійснено класифікацію вмінь моделювання економічних об'єктів відповідно до складових процесу моделювання; визначено педагогічні умови, що забезпечують ефективність формування вмінь моделювання у студентів вищих економічних навчальних закладів у процесі самостійної навчальної діяльності.

Ключові слова: педагогічні умови, моделювання, уміння, студент, вищий економічний навчальний заклад.

Тюрина Д. Н. Педагогические условия формирования умений моделирования у студентов высших экономических учебных заведений в процессе самостоятельной работы.

В статье осуществлена классификация умений моделирования экономических 